\title{
The Effect of Psychological Behavior and Rational Factors Toward the Decision of Customer to Save Money on Baitul Maal Wat Tamwil (BMT) Al Hijrah at Koperasi Agro Niaga (KAN) Jabung Malang East Java, Indonesia
}

\section{Salim Al Idrus}

Economic Faculty, Department of Management, Islamic State University of Maulana Malik Ibrahim Malang, $\mathrm{PBI}$, Indonesia

\section{Abstract}

The development of Syariah finance institution whether in the form of banking institution, cooperative or Baitul Maalwat Tamwil (BMT) is rapidly taking the attention of people. As a new Syariah institution, BMT Al Hijrah KAN Jabung must understand

Corresponding Author:

Salim Al Idrus

salim.alaydrus@yahoo.com

Received: 25 February 2018

Accepted: 26 May 2018

Published: 26 June 2018

Publishing services provided by Knowledge E

(c) Salim Al Idrus. This article is distributed under the terms of the Creative Commons

Attribution License, which permits unrestricted use and redistribution provided that the original author and source are credited.

Selection and Peer-review under the responsibility of the ICIFEB Conference Committee. the factors that influence the decision-making of costumer in saving. The aim of this research is to recognize the psychological and rational influence on the customer to save at BMT Al Hijrah KAN Jabung. It also intends to know the dominant influence variable to the saving decision. This study is an explanatory research that explains the causal relation and hypothesis examination. The approach used in this research is quantitative approach. The analytical technique used are: validity and reliability test, double regression test, $F$ test and $T$ test. The result of the study shows that the psychological and rational factors that consist of motivation $\left(X_{1}\right)$, learning $\left(X_{2}\right)$, attitude $\left(X_{3}\right)$, perception $\left(X_{4}\right)$ and rates of return $\left(X_{5}\right)$ have strong relation and significant influence on the costumer's decision to save at BMT Al Hijrah KAN Jabung $(Y)$. Variables that have a dominant influence on the purchasing decisions in a variable rate of return $\left(X_{5}\right)$.

Keywords: motivation, learning, attitude, perception, rales of return, saving decision

\section{Introduction}

Since the economic crisis that happened in Indonesia in 1997, BMT has grown to be the alternative of economic condition restoration in Indonesia [1]. Besides, BMT's presence is expected to be the tool in distributing fund for little business exertion with ease and clarity, because it is based on ease and without profit; hopefully, it can 
improve/increase the low-living standards of the society as well as BMT Al Hijrah KAN Jabung Malang East Java as the Syariah financial institution that has high enough potential because it is not only supported by surrounding society condition, but also has good Human Resource quality since the BMT is born from a famous cooperative. One who supports on that Syariah financial institution existence is PT. Bank Muamalat Indonesia, Malang branch. Known that more than 99 percent of Jabung people are Islamic and their Islamic pattern are very strong [2].

According to Marketing Manager BSM Yogyakarta Branch, Arie Nur Irwan, the saving money customer type can be grouped into: rational customer is the customer who saves money in Syariah bank not only owing to the psychological factor, but also due to the profit-gain factor or the ratio percentage which acquired from it [3]. Now, according to President Director of Bank Mega Syariah Indonesia (BMSI), Budi Wisakseno, the definition of 'rational customer' is the one who transacts with Syariah system just because of business calculation, not because of religious grudge [4].

Moreover, according to Burhanuddin Abdullah, nowadays many customers choose Syariah bank because of rational reasons like the profit of third-hand fund production share which is high enough as compared to the profit which is bid by conventional banking. Therefore, Burhanuddin does not worry about rush or take over defrayal to conventional bank, because rational customers have calculation for that [5]. Due to this, the banking management side is expected to understand consumer behavior in taking every decision on saving money or defrayal, as said by Kotler [6]: 'understanding consumer behaviour and knowing customer'. On that account, consumer behavior analysis is the first step to find out the motif which is undergird the customer applicant to save money at Syariah financial institution. Based on the aforementioned explanation, it is interesting to analyze various society behaviors in saying money at Syariah financial institution including BMT Al Hijrah KAN Jabung East Java which has various saving product that is offered, also behaviors from customers who have different motif in saving that certainly will influence their behavior in deciding their choice to save their fund.

The psychological factors of costumer behavior have been grouped as: motivation, learn, attitude and perception [7] and customer rational factor is profit factor rate $[8,9]$.

\section{Hypothesis}

1. Psychological behaviors (motivation $\left(X_{1}\right)$, learning $\left(X_{2}\right)$, attitude $\left(X_{3}\right)$, perception $\left(X_{4}\right)$ and rational behaviors simultaneously and partially profit level $\left(X_{5}\right)$ have 


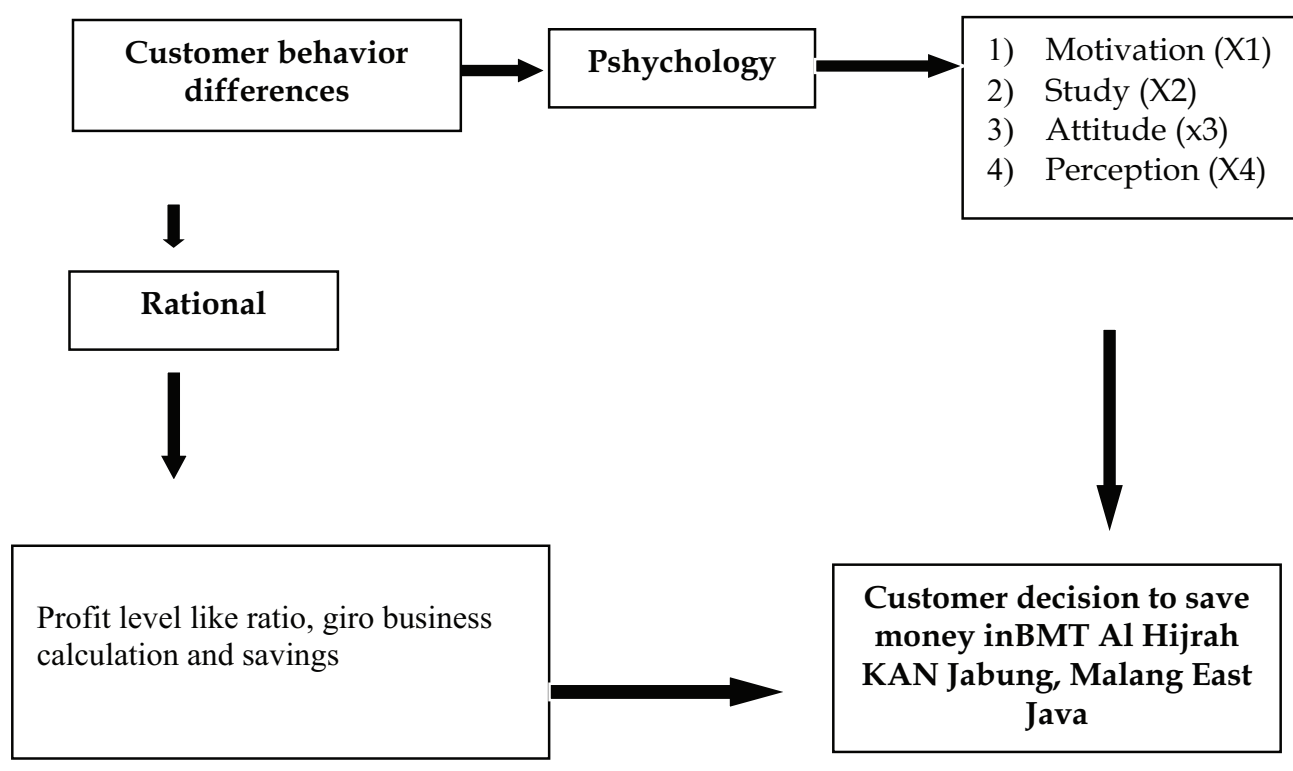

Figure 1: Concept design. Source: Data processing, 2013.

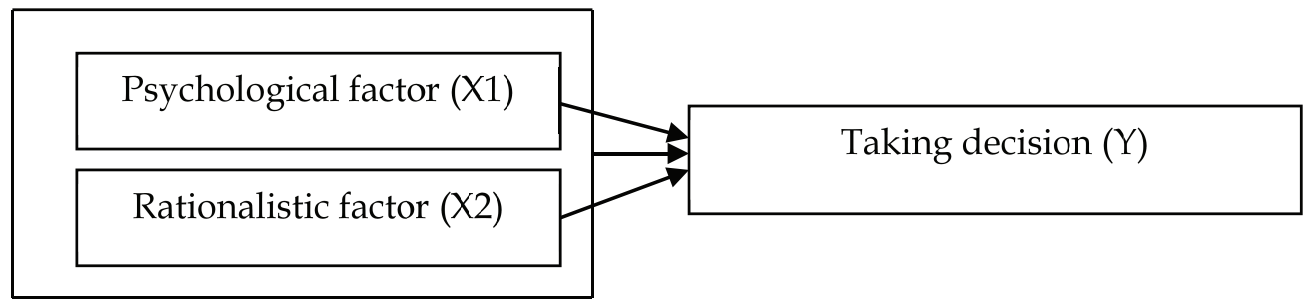

Figure 2: Concept and hypothesis model. Source: Data processing, 2013.

influence in client's decision of saving in BMT Al Hijrah KAN Jabung Malang East Java.

2. Rationalistic behavior (profit level/ $\mathrm{X}_{5}$ ) is the most dominant indicator that affects a client's decision of saving in BMT Al Hijrah KAN Jabung Malang East Java.

\section{Method}

This research belongs to associative research and is a research that aims to know the relationship between two variables or more [10]. From this research, a theory will be built that can be useful to explain factors that affect a client's decision of saving in BMT Al Hijrah KAN Jabung Malang East Java. 


\section{Population and Sampling Technique}

Population is generalization territorial contains object or subject has specific quality and characteristic which is decided by researcher to be learned and then summarized [11]. The population in this research are all of the customers who save money in BMT Al Hijrah KAN Jabung Malang, which is about 1.662 customers. The sample of this research is customer of BMT Al Hijrah KAN Jabung Malang East Java. For determining the amount of samples that is chosen, Slovin's formula from Umar [12] has been used, that is:

$$
n=\frac{N}{1+N(e)^{2}},
$$

where:

$\mathrm{n}$ = sample size

$\mathrm{N}=$ population size

$\mathrm{e}=$ inaccurate sag percent because of mistaking sample that can be accepted 5 percent. Using those formula, so the amount of samples are as follows:

$$
\mathrm{n}=\frac{1662}{1+1662(0,1)^{2}}=99.94=100 \text { costumer (integration). }
$$

The method of taking sample used is accidental sampling, determining the sample technique based on accidents, that is, whoever meets the researcher can be used as a sample without seeing the stratum of that population, it is done because population's member need to be considered as homogen [13].

\section{Result and Discussion}

Based on the result of bifilar linier regression test, the acquired result has been provided in Table 1 and the equation as follows:

From the Multiple Linear Regression Analysis in Table 1, we can assume the following equation:

$$
Y=a+b 1 \times 1+b 2 \times 2+b 3 \times 3+b 4 \times 4+b 5 \times 5+e,
$$

where: $\mathrm{Y}=$ Dependent variable that is purchasing decision

$$
\begin{aligned}
& \mathrm{a}=\text { constant } \\
& \mathrm{b}_{1.5}=\text { regression coefficient of independent variable } \\
& \mathrm{x}_{1}=\text { motivation } \\
& \mathrm{x}_{2}=\text { learning } \\
& \mathrm{x}_{3}=\text { attitude }
\end{aligned}
$$


TABLE 1: Result of Multiple Linier Regression Analysis.

\begin{tabular}{|c|c|c|c|c|c|}
\hline \multirow[t]{2}{*}{ Model } & \multicolumn{2}{|c|}{ Unstandardized Coefficients } & \multirow{2}{*}{$\begin{array}{c}\text { Standardized } \\
\text { Coefficients } \\
\text { Beta }\end{array}$} & \multirow[t]{2}{*}{$\mathbf{t}$} & \multirow[t]{2}{*}{ Sig. } \\
\hline & B & Std. Error & & & \\
\hline (Constant) & 0.082 & 0.189 & & 0.435 & 0.665 \\
\hline $\mathbf{X}_{1}$ & 0.415 & 0.074 & 0.461 & 5.642 & 0.000 \\
\hline$X_{2}$ & 0.236 & 0.056 & 0.235 & 4.172 & 0.000 \\
\hline$x_{3}$ & 0.026 & 0.072 & 0.032 & 0.356 & 0.723 \\
\hline$X_{4}$ & -0.155 & 0.062 & -0.134 & -2.507 & 0.014 \\
\hline$X_{5}$ & 0.450 & 0.052 & 0.475 & 8.612 & 0.000 \\
\hline
\end{tabular}

$\mathrm{x}_{4}=$ perception

$\mathrm{x}_{5}=$ profit level

e = error standard

Hence, it will be:

$$
Y=0.082+0.0415 X_{1}+0.236 X_{2}+0.026 X_{3}+(-0.155) X_{4}+0.450 X_{5}+e .
$$

The result of the analysis can be interpreted as the following:

1. Constant $(a)=0.082$ showing the positive inclination, meaning if there is no influence motivation $\left(X_{1}\right)$, learning $\left(X_{2}\right)$, attitude $\left(X_{3}\right)$, perception $\left(X_{4}\right)$, profit level $\left(X_{5}\right)$, we still get the positive inclination to the customer's decision in saving their money at BMT Al Hijrah KAN Jabung (Y).

2. For each contribution in every variable of motivation $\left(X_{1}\right)$ will influence the decision in saving money at BMT Al Hijrah KAN Jabung $(Y)$ by 0.415 with assumption that variable of learning $\left(X_{2}\right)$, attitude $\left(X_{3}\right)$, perception $\left(X_{4}\right)$, and profit level $\left(X_{5}\right)$ are constant.

3. For each contribution in every variable of learning $\left(X_{2}\right)$ will influence the decision in saving money at BMT Al Hijrah KAN Jabung $(Y)$ by 0.262 with assumption that variable of motivation $\left(X_{1}\right)$, attitude $\left(X_{3}\right)$, perception $\left(X_{4}\right)$ and profit level $\left(X_{5}\right)$ are constant.

4. For each contribution in every variable of attitude $\left(X_{3}\right)$ will influence the decision in saving money at BMT Al Hijrah KAN Jabung $(Y)$ by 0.026 with assumption that 
variable of motivation $\left(X_{1}\right)$, learning $\left(X_{2}\right)$, perception $\left(X_{4}\right)$ and profit level $\left(X_{5}\right)$ are constant.

5. For each contribution in every variable of perception $\left(X_{4}\right)$ will influence the decision in saving money at BMT Al Hijrah KAN Jabung ( $Y$ ) by -0.155 with assumption that variable of motivation $\left(X_{1}\right)$, learning $\left(X_{2}\right)$, attitude $\left(X_{3}\right)$, and profit level $\left(X_{5}\right)$ are constant.

6. For each contribution in every variable of profit level $\left(X_{5}\right)$ will influence the decision in saving money at BMT Al Hijrah KAN Jabung $(Y)$ by 0.450 with assumption that variable of motivation $\left(X_{1}\right)$, learning $\left(X_{2}\right)$, attitude $\left(X_{3}\right)$ and perception $\left(X_{4}\right)$ are constant.

From that result we can conclude that variable of psychology consists of motivation $\left(X_{1}\right)$, learning $\left(X_{2}\right)$, attitude $\left(X_{3}\right)$, perception $\left(X_{4}\right)$ and rational variable, that is the level of profit $\left(X_{5}\right)$ simultaneously have an influence on the customer's decision in saving money at BMT Al Hijrah KAN Jabung Malang East Java (Y).

Correlation coefficient ( $R$ ) by 0.949 shows the strong positive relation between motivation $\left(X_{1}\right)$, learning $\left(X_{2}\right)$, attitude $\left(X_{3}\right)$, perception $\left(X_{4}\right)$ and profit level $\left(X_{5}\right)$ with the decision in saving money $(Y)$. This can be indicated as a strong relation, as it is known that a relation is called perfect if its correlation coefficient reaches to 100 percent or verge on 1 (Bungin, 2010:184).

From the percentage Adjusted $R$ Square by 0.894 or 89.4 percent. This numeral shows that the variables of motivation $\left(X_{1}\right)$, learning $\left(X_{2}\right)$, attitude $\left(X_{3}\right)$, perception $\left(X_{4}\right)$ and profit level $\left(X_{5}\right)$ did contribution to the customer's decision variable in saving money at BMT Al Hijrah KAN Jabung Malang East Java (Y) by 89.4 percent, while the rest 10.6 percent were influenced by other unanalyzed reasons.

From analysis $F$, we can know that $\mathrm{F}_{\text {arithmetic }}(168.805)>$ from $\mathrm{F}_{\text {table }}(2.31)$, with the significance $0.000<0.05$ (alfa in reliance extent of 95 percent), meaning that $\mathrm{H}_{0}$ is unacceptable and $\mathrm{Ha}$ is acceptable; hence, 'Variable of Psychological and Rational Factor' influences significantly the customer's decision in saving money at Al Hijrah KAN Jabung Malang East Java.

The results of $t$-test analysis also obtained the indicator from the independent variables $(X)$ that dominantly influences the customer's decision to saving money at BMT Al Hijrah KAN Jabung Malang East Java $(Y)$, which is profit $\left(X_{5}\right)$. This is evidenced by $t_{\text {arithmetic }}$ value of the variable profit level $\left(X_{5}\right)$ by 8.612 , which has the greatest value than the other variables, that is, an indicator of motivation $\left(X_{1}\right)$ by 5.642 ; learn $\left(X_{2}\right)$ by 4.172; attitude $\left(X_{3}\right)$ by 0.356 ; and the perception indicator $\left(X_{4}\right)$ by -2.507 . 
Thus, the second hypothesis that explains that the profit-level indicator $\left(X_{5}\right)$ is the dominant influencer of the decision to saving money at BMT Al Hijrah KAN Jabung Malang East Java is accepted.

\section{Summary}

The results of this research show that the multiple linear regression analysis showed that the psychological variables and the rationale consist from motivation $\left(X_{1}\right)$, learning $\left(X_{2}\right)$, attitude $\left(X_{3}\right)$, perception $\left(X_{4}\right)$ and profit level $\left(X_{5}\right)$ that simultaneously have a significant influence on the decisions of customers to saving money at BMT Al Hijrah KAN Jabung Malang East Java (Y), where F count of 168.805 and the significant level $\mathrm{F}<5$ percent $(0.000<0.05)$. Based on the results of the analysis tests, the partial regression is an independent variable that consist of motivation $\left(X_{1}\right)$, learning $\left(X_{2}\right)$, attitude $\left(X_{3}\right)$, perception $\left(X_{4}\right)$ and profit level $\left(X_{5}\right)$ has a positive and significant effect, but the attitude of indicator $\left(X_{3}\right)$ insignificantly to the customer's decision to saving money at BMT Al Hijrah KAN Jabung Malang East Java ( $Y$ ).

Furthermore, the profit level $\left(X_{5}\right)$ is the dominant indicator that influences the customer's decision to save money at BMT Al Hijrah KAN Jabung Malang East Java ( $Y$ ), because it has the greatest significance, which is $0.000>0.005$, because $t$ counted on the largest (8.612), so the second hypothesis that explained the profit level $\left(X_{5}\right)$ is the most dominant indicator to influence the customer's decision to save money at BMT Al Hijrah KAN Jabung Malang East Java is accepted.

\section{References}

[1] Antonio, Muhammad Syafi'i, 1999. Bank Syariah Wacana Ulama danCendekiowon.Jakarta:Tazkia Institute.

[2] __ , 2001. Bank Syari'ah Dari Teori Ke Praktek. Jakarta:Gema Insani Press.

[3] __ 2009. Bank Syariah Bagi Bankir dan Praktisi Keuangan.Jakarta : Tazkia Institute.

[4] Arikunto, Suharsimi, 2002. Prosedur Penelition Suatu Pendekaton Praktek. Edisi Revisi V, Jakarta: PT. Rineka Cipta.

[5] Biro Pusat Statistik Kabupaten Malang. 2012. Kecamatan Jabung 2012 dalam Angka. Malang.

[6] Burhan, Bungin. 2010. Metodologi Penelitian Kuantitatif. Jakarta: Kencana Prenada Media. 
[7] Engel, James F. dkk, 1994. Perilakn Konsumen. Edisi Keenam, Jakarta: Binarupa Aksara.

[8] Enggar, Nursasi,2013, Analisis Pengambilan Keputusan Keuangan dan Bisnis Pada Perusahaan Property dan Real Estate, Jurnal Ekonomi dan Bisnis Islam Iqtishoduna, Vol. 9, Nomor 1.

[9] Hurriyati, Ratih, 2005. Bauran Pemasaran dan Loyalilas Konsumen Fokus Pada Konsumen Kartu Kredit Perbankan. Bandung: Alfabeta.

[10] Khotler, Philip, 2002. Manajemen Pemasaran. Edisi Milenium Dua, Penerbit Jakarta:PT Prenhallindo.

[11] Kotler,Philips dan Amstrong, 2001. Prinsip-Prinsip Pemasaran. Jakarta: Erlanga.

[12] Mangkunegara, Anwar Prabu, 2002. Perilaku Konsumen. Edisi Revisi.Bandung: PT Refika Aditama.

[13] Prasetijo, Ristiyanti dan John, J.O.I. Ihalauw, 2005. Perilaku Konsumen. Yogyakarta: Andi.

[14] Sugiyono, 2002. Metode Penelition Bisnis. Bandung: CV Alfabeta.

[15] Sugiyono, 2008.Metode Penelition kuantitatif. Kualitatif dan $R \& D$. Bandung: Alfabeta.

[16] Sumarwan, Ujang, 2004. Perilaku Konsumen Teori dan Penerapannya dalam Pemasaran. Bogor: Ghalia Indonesia.

[17] Susiana, 2010, Analisis Pembiayaan Mudharabah Pada PT Bank Tabungan Negara (Persero) TBK Kantor Cabang Syariah Malang, Jurnal Ekonomi dan Bisnis Islam lqtishoduna, Vol. 6, Nomor 3.

[18] Umar, Husein, 1996. Metode Penelition Untuk Penelition dan Tesis Bisnis. Jakarta: PT Raja Grafindo Persada.

[19] Wafa, Agus Khairul Mohammad dan Nasrodin. 2008. Bait Al-Maal Wa at-Tamwiil. Yogyakarta: Ull.

[20] Yumanita Diana, Ascarya, 2005. Bank Syariah Gambaran Umum. Jakarta: Pusat Kependidikan dan Studi Kebanksentralan (PPSAK) Bank Indonesia.

[21] Yusanto dan Widjajakusuma, 2002. Pengantar Manajemen Syariat. Jakarta: Khairul Bayan. 